\title{
Diallyl Trisulfide, the Antifungal Component of Garlic Essential Oil and the Bioactivity of Its Nanoemulsions Formed by Spontaneous Emulsification
}

\author{
Xue Gong ${ }^{1}$, Xiaoqian Su ${ }^{1,2}$ and Hongjia Liu ${ }^{1, *}$ \\ 1 State Key Laboratory for Managing Biotic and Chemical Threats to the Quality and Safety of Agro-Products, \\ Zhejiang Academy of Agricultural Sciences, Hangzhou 310021, China; gongxuezhenbang@163.com (X.G.); \\ aaa9493@163.com (X.S.) \\ 2 School of Agricultural and Food Science, Zhejiang Agriculture and Forestry University, \\ Hangzhou 311300, China \\ * Correspondence: liuhongjia@zaas.ac.cn
}

check for updates

Citation: Gong, X.; Su, X.; Liu, H. Diallyl Trisulfide, the Antifungal Component of Garlic Essential Oil and the Bioactivity of Its

Nanoemulsions Formed by Spontaneous Emulsification. Molecules 2021, 26, 7186. https:// doi.org/10.3390/molecules26237186

Academic Editor: Francesca

Mancianti

Received: 29 October 2021

Accepted: 25 November 2021

Published: 26 November 2021

Publisher's Note: MDPI stays neutral with regard to jurisdictional claims in published maps and institutional affiliations.

Copyright: (C) 2021 by the authors. Licensee MDPI, Basel, Switzerland. This article is an open access article distributed under the terms and conditions of the Creative Commons Attribution (CC BY) license (https:/ / creativecommons.org/licenses/by/ $4.0 /)$.

\begin{abstract}
The aim of this study was to evaluate the chemical compounds of garlic essential oil (EO), and determine the antifungal efficacy of garlic EO and its major components, diallyl trisulfide and its nanoemulsions against wood-rotting fungi, Trametes hirsuta and Laetiporus sulphureus. GC-MS analysis revealed that the major constituents of garlic EO were diallyl trisulfide (39.79\%), diallyl disulfide $(32.91 \%)$, and diallyl sulfide $(7.02 \%)$. In antifungal activity, the $\mathrm{IC}_{50}$ value of garlic EO against T. hirsuta and L. sulphureus were 137.3 and $44.6 \mu \mathrm{g} / \mathrm{mL}$, respectively. Results from the antifungal tests demonstrated that the three major constituents were shown to have good antifungal activity, in which, diallyl trisulfide was the most effective against T. hirsuta and L. sulphureus, with the $\mathrm{IC}_{50}$ values of 56.1 and $31.6 \mu \mathrm{g} / \mathrm{mL}$, respectively. The diallyl trisulfide nanoemulsions showed high antifungal efficacy against the examined wood-rotting fungi, and as the amount of diallyl trisulfide in the lipid phase increases, the antifungal efficacy of the nanoemulsions increases. These results showed that the nanoemulsions and normal emulsion of diallyl trisulfide have potential to develop into a natural wood preservative.
\end{abstract}

Keywords: garlic; diallyl trisulfide; wood-rotting fungi; nanoemulsion; antifungal activity

\section{Introduction}

Worldwide, it is generally believed that the problem faced in the management of wood structure was the biodegradation of wood by fungi and termites [1-3]. Wood decay fungi are mainly divided into Trametes, Lenzites, and Laetiporus genera [4]. Recently, the control of decay fungi has largely relied on the use of synthetic pesticides, such as Acid Copper Chromate (ACC), Ammonical Copper Quat (ACQ), Chromated Copper Arsenate (CCA), cyproconazole and propiconazole [5]. However, the excessive use of preservative chemicals led to residues in the environment, which are harmful to humans and the environment [6,7]. An effective measure to solve these problems is to develop new wood protection agents. EOs have characteristics of non-residual, biodegradable, and harmonious environment, which can be used as potential for the development of new preservatives $[2,8,9]$. Recently, many essential oils or extracts have been evaluated for the control of wood decay fungi, such as Syzgium aromaticum [1], Pinus rigida [10], Rumex abyssinicus [11], Origanum vulgare [2], Tectona grandis [7], Allium cepa [11], Amorphophallus konjac [12], and Lannea coromandelica [13]. These results showed that EOs have the potential to develop into green wood preservatives to control wood decay fungi.

Since ancient times, garlic (Allium sativum L.) has played an important role in diet and medicine [14,15]. Particularly today, the medicinal values of garlic are more extensive [16]. Garlic is rich in organic sulfur compounds, which are responsible for the renowned medicinal properties including antioxidant [17], anticancer [18], antifungal [19], antidiabetic [20], 
anti-inflammatory [21], antimicrobial [22], cardioprotective [23], anti-atherosclerotic [24], immunomodulatory [25], and antihypertensive [26] activities. In addition, garlic EO has excellent insecticidal effects. According to the previous reports, garlic EO has good insecticidal activity against vector pests, such as Aedes aegypti $[27,28]$, Culex pipiens [15,29], and Rhipicephalus microplus [30]; storage and construction pests, such as Sitophilus zeamais and Tribolium castaneum [31-33], Reticulitermes speratus [34], Ephestia kuehniella [35], Callosobruchus maculatus [36], Sitotroga cerealella [37], and Tenebrio molitor [38]; and crop pests, such as codling moth [39], Tetranychus urticae [40], Cacopsylla chinensis [41], Tegolophus hassani [42], and Tyrophagus putrescentiae [43].

Although garlic EO has been shown to have outstanding efficacy in agricultural protection, there is almost no report on the antifungal efficacy of the garlic EO and its major components against wood-rotting fungi. In this study, we hypothesized that garlic EO and its constituents have antifungal efficacy against wood-rotting fungi, Trametes hirsuta and Laetiporus sulphureus.

However, the application of garlic oil in these processes is difficult due to its low water solubility. If the water solubility of garlic oil is improved, it can be used in many other fields, such as insecticide and fungicide. Therefore, garlic oil is encapsulated in oil-inwater $(\mathrm{O} / \mathrm{W})$ emulsions or nanoemulsions, allowing this oil to be used in agrochemical applications. The use of the low-energy spontaneous emulsification method to produce essential oil nanoemulsions is suitable for food and agriculture.

Therefore, the aim of this study was (1) to investigate the garlic EO components; (2) to evaluate garlic EO and its major constituents against two wood-rotting fungi; and (3) to determine the activities of antifungal efficacy of its major compound diallyl trisulfide (DAT) nanoemulsions.

\section{Results}

\subsection{Antifungal Activity of Garlic EO}

The efficacy of garlic EO against two wood decay fungi increased significantly with an increased concentration (for T. hirsuta, $\mathrm{F}=182.4 ; \mathrm{df}=4,10 ; p<0.0001$; for L. sulphureus, $\mathrm{F}=966.6 ; \mathrm{df}=4,10 ; p<0.0001$ ) (Figures 1 and 2). The $\mathrm{IC}_{50}$ value of garlic EO against T. hirsuta and L. sulphureus showed high toxicity with 137.3 and $44.6 \mu \mathrm{g} / \mathrm{mL}$, respectively (Table 1).

Table 1. $\mathrm{IC}_{50}$ values $(\mu \mathrm{g} / \mathrm{mL})$ of garlic EO and its major components against wood decay fungi T. hirsuta and L. sulphureus.

\begin{tabular}{ccccc}
\hline \multirow{2}{*}{ Components } & \multicolumn{2}{c}{ T. hirsuta } & \multicolumn{2}{c}{ L. sulphureus } \\
\cline { 2 - 5 } & $\left.\mathbf{I C}_{\mathbf{5 0}} \mathbf{( C I}_{\mathbf{9 5}}\right)$ & $\chi^{\mathbf{2}}$ & $\mathbf{I C}_{\mathbf{5 0}} \mathbf{( C I}_{\mathbf{9 5}} \mathbf{)}$ & $\chi^{\mathbf{2}}$ \\
\hline garlic EO & $137.3(83.1-276.3)$ & 0.439 & $44.6(31.7-57.8)$ & 9.894 \\
diallyl sulfide & $>1000$ & - & $>1000$ & - \\
diallyl disulfide & $116.2(77.2-184.6)$ & 1.129 & $73.2(54.4-95.7)$ & 3.381 \\
diallyl trisulfide & $56.1(42.7-71.2)$ & 8.592 & $31.6(23.5-38.7)$ & 2.626 \\
\hline
\end{tabular}



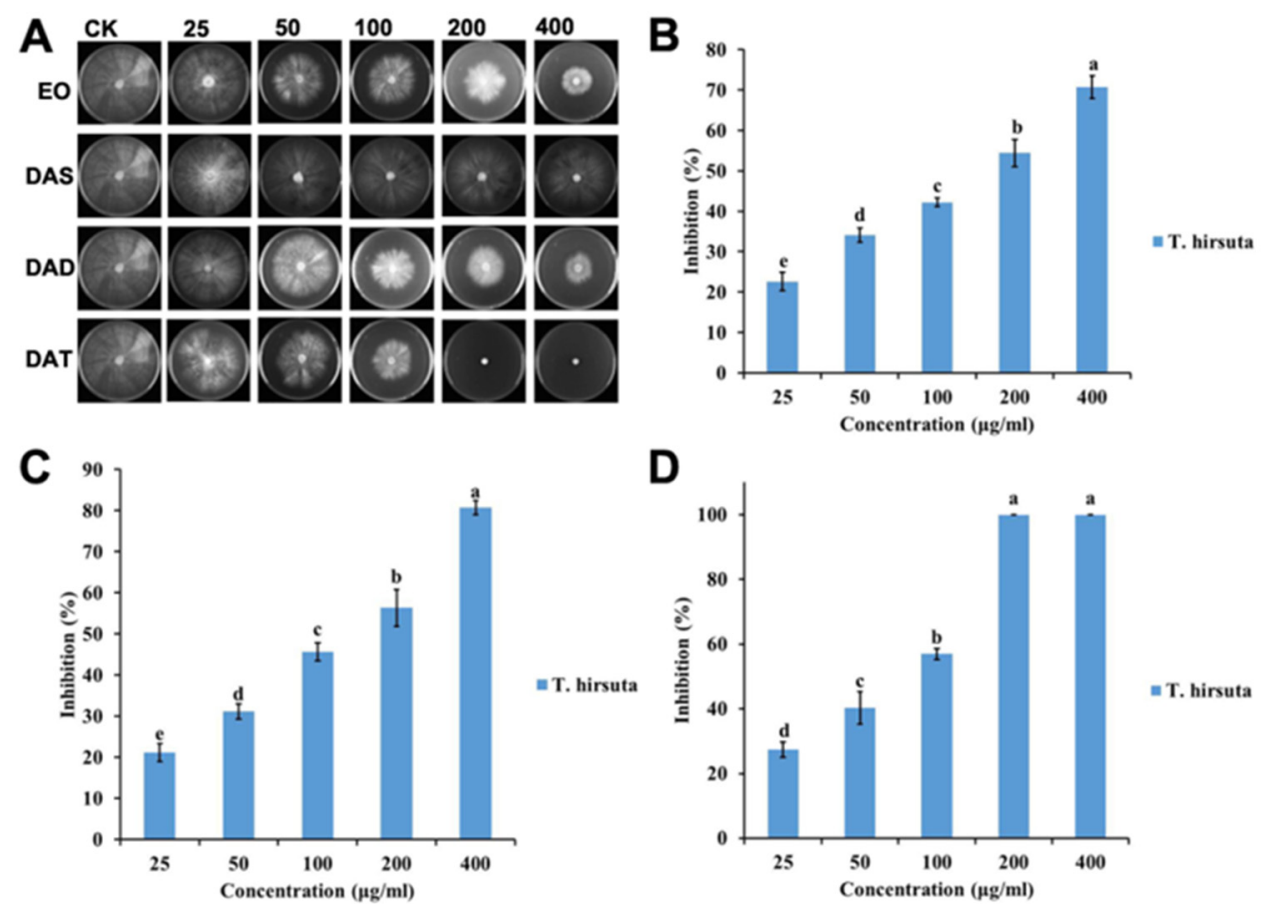

Figure 1. Antifungal activities of garlic EO and its major components against white decay fungi T. hirsuta: (A) Chart of antifungal effect; (B) garlic EO; (C) diallyl disulfide; (D) diallyl trisulfide. Mean $( \pm \mathrm{SD})$ values with different letters (a-e) are significantly different at the level of $p<0.05$, according to Scheffe's test.
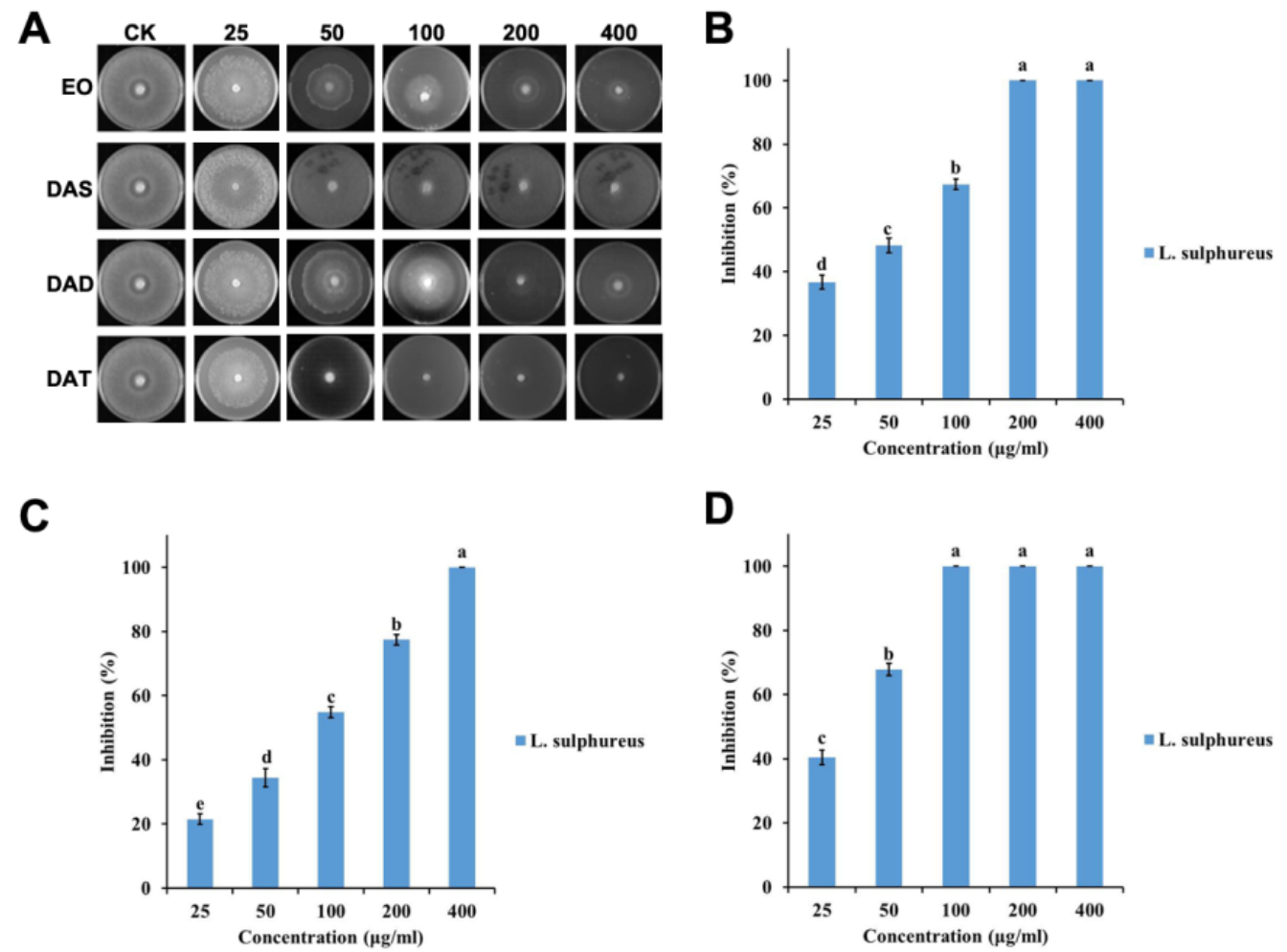

Figure 2. Antifungal activities of garlic EO and its major components against brown decay fungi L. sulphureus: (A) Chart of antifungal effect; (B) garlic EO; (C) diallyl disulfide; (D) diallyl trisulfide. Mean $( \pm \mathrm{SD})$ values with different letters (a-e) are significantly different at the level of $p<0.05$, according to Scheffe's test. 


\subsection{Chemical Composition of Garlic EO}

The chemical characteristic of garlic EO was summarized in Table 2. A total of nine constituents accounting for $98.13 \%$ of garlic EO were identified, and the major constituents detected were diallyl trisulfide $(39.79 \%)$, diallyl disulfide $(32.91 \%)$, and diallyl sulfide (7.02\%) (Figure 3).

Table 2. Chemical composition of the garlic EO.

\begin{tabular}{cccc}
\hline No. & Compound & RI & $\%$ \\
\hline 1 & Diallyl sulfide & 849 & 7.02 \\
2 & Limonene & 1027 & 1.04 \\
3 & Diallyl disulfide & 1077 & 32.91 \\
4 & Linalool & 1097 & 3.62 \\
5 & Methyl allyl trisulfide & 1128 & 1.06 \\
6 & 3-vinyl-[4H]-1,2- & 1134 & 1.83 \\
7 & dithiin & 1290 & 3.72 \\
8 & Anethole & 1296 & 39.79 \\
9 & Diallyl trisulfide & 1540 & 7.14 \\
Total & Diallyl tetrasulfide & & 98.13 \\
\hline
\end{tabular}<smiles>C=CCSCC=C</smiles>

(a)<smiles>C=CCSSCC=C</smiles>

(b)<smiles>C=CCSSSCC=C</smiles>

(c)

Figure 3. Chemical structure of the three major constituents of garlic EO: (a) Diallyl sulfide, (b) diallyl disulfide, and (c) diallyl trisulfide.

\subsection{Antifungal Activity of Compounds}

Diallyl disulfide showed a significant variation in inhibition rate among the different concentrations (for T. hirsuta, $\mathrm{F}=220.1 ; \mathrm{df}=4,10 ; p<0.0001$; for L. sulphureus, $\mathrm{F}=876.2$; $\mathrm{df}=4,10 ; p<0.0001$ ) (Figures 1 and 2), with an $\mathrm{IC}_{50}$ value of 116.2 and $73.2 \mu \mathrm{g} / \mathrm{mL}$, respectively (Table 1). Diallyl trisulfide also showed a significant difference in inhibition rate at different concentrations (for T. hirsuta, $\mathrm{F}=510.0$; $\mathrm{df}=4,10 ; p<0.001$; for L. sulphureus, $\mathrm{F}=1203.9 ; \mathrm{df}=4,10 ; p<0.0001$ ) (Figures 1 and 2 ), with an $\mathrm{IC}_{50}$ value of 56.1 and $31.6 \mu \mathrm{g} / \mathrm{mL}$, respectively (Table 1 ).

The difference between the diallyl disulfide (for $T$. hirsuta, $\mathrm{F}=181.6$; $\mathrm{df}=9,20$; $p<0.0001$; for L. sulphureus, $\mathrm{F}=858.5 ; \mathrm{df}=9,20 ; p<0.0001$ ) and garlic $\mathrm{EO}$ (for T. hirsuta, $\mathrm{F}=374.2 ; \mathrm{df}=9,20 ; p<0.0001 ;$ for L. sulphureus, $\mathrm{F}=992.1 ; \mathrm{df}=9,20 ; p<0.0001$ ) for wood decay fungi was highly significant. In addition, this was significantly different between diallyl disulfide and diallyl trisulfide for wood decay fungi (for T. hirsuta, $\mathrm{F}=357.0$; $\mathrm{df}=9,20 ; p<0.0001$; for L. sulphureus, $\mathrm{F}=1061.3 ; \mathrm{df}=9,20 ; p<0.0001$ ). 


\subsection{Diallyl Trisulfide (DAT) Nanoemulsions on Particle Size}

As the concentration of diallyl trisulfide (DAT) in the lipid phase increases, the average droplet diameter decreases (Figure 4). When DAT in the lipid phase is $25 \%$, the minimum droplet diameter is $62.3 \mathrm{~nm}$. The average droplet size of the nanoemulsions is $120.7 \pm 4.2 \mathrm{~nm}$ and $62.3 \pm 2.5 \mathrm{~nm}$, respectively, when the DAT in the lipid is 5 and $20 \%$.

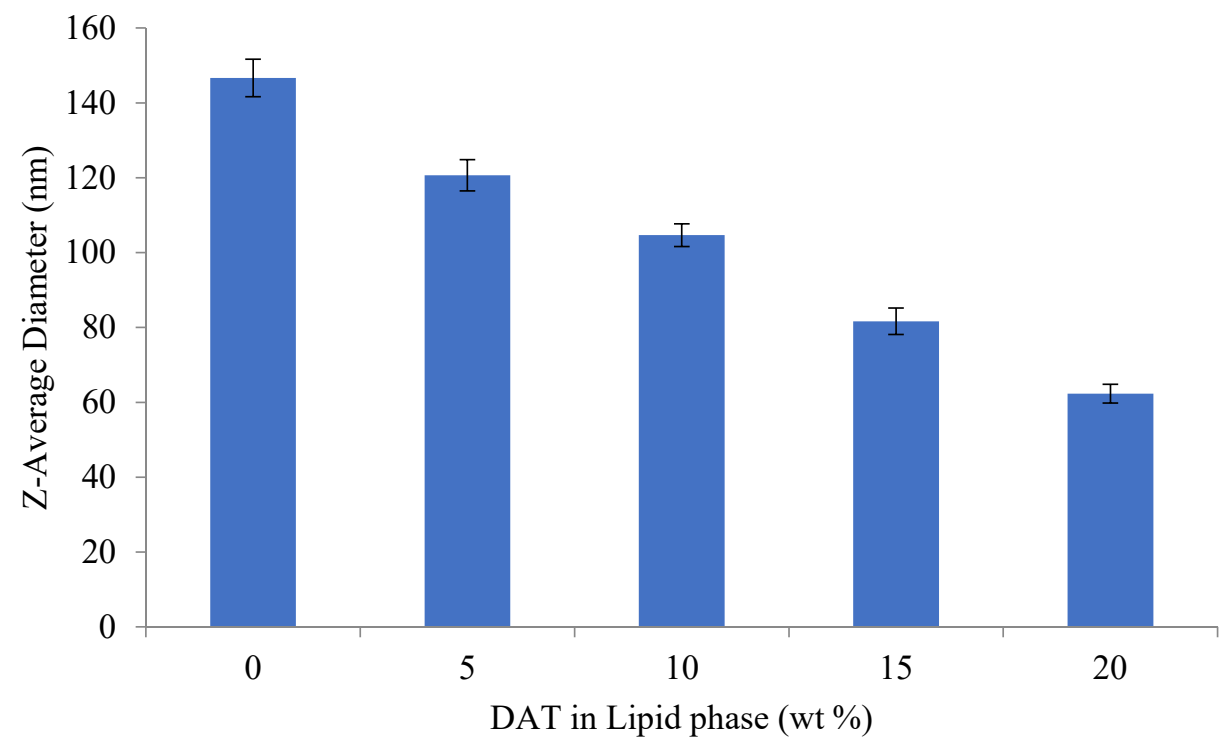

Figure 4. Effect of oil phase composition (wt \% DAT in oil phase) on the mean particle diameter of emulsions and nanoemulsions produced by spontaneous emulsification.

\subsection{Antifungal Activity of the Spontaneously Emulsified Diallyl Trisulfide (DAT) Nanoemulsions}

The antifungal activity of the nanoemulsions increases with the increase of diallyl trisulfide (DAT) concentration in the organic phase, whereby if the lipid phase of the nanoemulsions contains a higher level of DAT, less DAT can completely inhibit the growth of T. hirsuta and L. sulphureus (for T. hirsuta, $\mathrm{F}=491.1 ; \mathrm{df}=19,40 ; p<0.0001$; for L. sulphureus, $\mathrm{F}=408.9 ; \mathrm{df}=19,40 ; p<0.0001)($ Table 3$)$.

Here, $5 \%$ DAT nanoemulsions showed a significant variation in inhibition rate among the different concentrations (for T. hirsuta, $\mathrm{F}=515.2 ; \mathrm{df}=4,10 ; p<0.0001$; for L. sulphureus, $\mathrm{F}=601.0 ; \mathrm{df}=4,10 ; p<0.0001$ ) (Table 3), with an $\mathrm{IC}_{50}$ value of 54.8 and $31.8 \mu \mathrm{g} / \mathrm{mL}$, respectively (Table 4). In addition, $10 \%$ DAT nanoemulsions showed a significant variation in inhibition rate among the different concentrations (for T. hirsuta, $\mathrm{F}=388.7 ; \mathrm{df}=4,10$; $p<0.0001$; for L. sulphureus, $\mathrm{F}=268.5 ; \mathrm{df}=4,10 ; p<0.0001$ ) (Table 3), with an $\mathrm{IC}_{50}$ value of 48.7 and $29.9 \mu \mathrm{g} / \mathrm{mL}$, respectively (Table 4). Moreover, $15 \%$ DAT nanoemulsions showed a significant variation in inhibition rate among the different concentrations (for T. hirsuta, $\mathrm{F}=694.3 ; \mathrm{df}=4,10 ; p<0.0001 ;$ for L. sulphureus, $\mathrm{F}=425.9 ; \mathrm{df}=4,10 ; p<0.0001$ ) (Table 3), with an $\mathrm{IC}_{50}$ value of 46.1 and $27.8 \mu \mathrm{g} / \mathrm{mL}$, respectively (Table 4 ). Furthermore, $20 \%$ DAT nanoemulsions showed a significant variation in inhibition rate among the different concentrations (for T. hirsuta, $\mathrm{F}=1302.6 ; \mathrm{df}=4,10 ; p<0.0001$; for L. sulphureus, $\mathrm{F}=486.6$; $\mathrm{df}=4,10 ; p<0.0001$ ) (Table 3), with an $\mathrm{IC}_{50}$ value of 43.2 and $27.4 \mu \mathrm{g} / \mathrm{mL}$, respectively (Table 4). 
Table 3. Antifungal activities of diallyl trisulfide nanoemulsions against wood decay fungi T. hirsuta and L. sulphureus.

\begin{tabular}{|c|c|c|c|}
\hline \multirow{2}{*}{ DAT Levels in Lipid Phase (wt \%) } & \multirow{2}{*}{ Con. $(\mu g / m L)$} & \multicolumn{2}{|c|}{ Inhibition $(\%$, Mean \pm SD) } \\
\hline & & T. hirsuta & L. sulphureus \\
\hline \multirow{5}{*}{$5 \%$} & 25 & $28.52 \pm 1.70^{\mathrm{h}}$ & $41.85 \pm 3.90^{\mathrm{d}}$ \\
\hline & 50 & $40.74 \pm 4.21$ efg & $64.07 \pm 1.69^{c}$ \\
\hline & 100 & $58.52 \pm 3.40^{\mathrm{cd}}$ & $100^{\mathrm{a}}$ \\
\hline & 200 & $100^{\mathrm{a}}$ & $100^{\mathrm{a}}$ \\
\hline & 400 & $100^{\mathrm{a}}$ & $100^{\mathrm{a}}$ \\
\hline \multirow{5}{*}{$10 \%$} & 25 & $32.96 \pm 3.40 \mathrm{gh}$ & $44.81 \pm 5.25^{\mathrm{d}}$ \\
\hline & 50 & $45.56 \pm 4.44^{\mathrm{ef}}$ & $68.52 \pm 2.79 b c$ \\
\hline & 100 & $63.7 \pm 2.31 \mathrm{bc}$ & $100^{\mathrm{a}}$ \\
\hline & 200 & $100^{\mathrm{a}}$ & $100^{a}$ \\
\hline & 400 & $100^{\mathrm{a}}$ & $100^{\mathrm{a}}$ \\
\hline \multirow{5}{*}{$15 \%$} & 25 & $34.44 \pm 2.94 \mathrm{gh}$ & $47.41 \pm 1.70^{\mathrm{d}}$ \\
\hline & 50 & $47.41 \pm 2.79 \mathrm{e}$ & $74.81 \pm 1.70^{b}$ \\
\hline & 100 & $67.41 \pm 1.70^{b c}$ & $100^{\mathrm{a}}$ \\
\hline & 200 & $100^{\mathrm{a}}$ & $100^{a}$ \\
\hline & 400 & $100^{\mathrm{a}}$ & $100^{\mathrm{a}}$ \\
\hline \multirow{5}{*}{$20 \%$} & 25 & $36.67 \pm 1.11^{\text {fgh }}$ & $47.78 \pm 2.94^{\mathrm{d}}$ \\
\hline & 50 & $50.37 \pm 2.30 \mathrm{de}$ & $76.30 \pm 2.80^{b}$ \\
\hline & 100 & $69.63 \pm 1.70^{b}$ & $100 \mathrm{a}$ \\
\hline & 200 & $100^{\mathrm{a}}$ & $100 \mathrm{a}$ \\
\hline & 400 & $100^{\mathrm{a}}$ & $100 \mathrm{a}$ \\
\hline Df & & 19 & 19 \\
\hline F-value & & 491.067 & 408.916 \\
\hline$p$ & & 0.0001 & 0.0001 \\
\hline
\end{tabular}

Table 4. $\mathrm{IC}_{50}$ values $(\mu \mathrm{g} / \mathrm{mL})$ of diallyl trisulfide nanoemulsions against wood decay fungi T. hirsuta and L. sulphureus.

\begin{tabular}{ccccc}
\hline \multirow{2}{*}{ DAT Levels in Lipid Phase (wt \%) } & \multicolumn{2}{c}{ T. hirsuta } & \multicolumn{2}{c}{ L. sulphureus } \\
\cline { 2 - 5 } & $\mathbf{I C}_{\mathbf{5 0}}\left(\mathbf{C I}_{\mathbf{9 5}}\right)$ & $\chi^{\mathbf{2}}$ & $\mathbf{I C}_{\mathbf{5 0}}\left(\mathbf{C I}_{\mathbf{9 5}}\right)$ & $\chi^{\mathbf{2}}$ \\
\hline $5 \%$ & $54.8(41.4-69.6)$ & 8.300 & $31.8(23.4-39.2)$ & 3.756 \\
$10 \%$ & $48.7(35.6-62.5)$ & 7.115 & $29.9(21.2-37.1)$ & 3.148 \\
$15 \%$ & $46.1(33.4-59.3)$ & 5.943 & $27.8(19.1-34.7)$ & 1.815 \\
$20 \%$ & $43.2(30.6-56.0)$ & 5.325 & $27.4(18.7-34.2)$ & 1.679 \\
\hline
\end{tabular}

\section{Discussion}

The results clearly showed that garlic EO has an inhibitory efficacy against two wood decay fungi (Table 1). Similarly, the garlic EO was demonstrated to possess antifungal activity against the agents of anthracnose in avocado, Colletotrichum gloeosporioides [44]; of tomato diseases, Penicillium expansum and Rhizopus stolonifer [45]; Aspergillus parasiticus, A. niger [46] and A. terreus [47]; Fusarium oxysporum [48] and F. thapsinum [47]; of grapes post-harvest disease, Botrytis cinerea [49]; Penicillium citrinum [50] and P. funiculosum [47]. In addition, in the previous reports, garlic EO or extract exhibits insecticidal, antifeedant, and repellent activities against many insects and mites $[15,28,29,38,43]$. Therefore, garlic EO plays a very important role in protecting plants from pests and diseases during plant growth. Actually, garlic EO and extracts have been used to develop as a series of pest control products and are marketed as crop protection products to prevent and control many pest organisms.

The chemical composition of garlic EO revealed that nine compounds were detected. In particular, diallyl trisulfide $(39.79 \%)$, diallyl disulfide $(32.91 \%)$, diallyl tetrasulfide $(7.14 \%)$, and diallyl sulfide $(7.02 \%)$ were the major compounds. The results are consistent with those of previous reports. In general, diallyl trisulfide (33.4-50.43\%) was the major 
component of garlic EO [30,41,48,51]. However, there were significant differences in the major components of garlic EO. The previous study reported that allyl disulfide (49.13\%) was the principal constituent of garlic EO [29]. On the one hand, Li et al. [52] reported that 3-vinyl-4H-1,2-dithiin (31.89\%) was the major constituent of garlic EO. On the other hand, the major component of garlic EO was diallyl disulfide (29.08\%) [53]. In another investigation, Kimbaris et al. [15] reported that methyl allyl trisulfide (19.8\%) was the main constituent of garlic EO. Various studies indicated that the difference in the relative proportion of these sulfides may be caused by the extraction temperature, extraction time or both.

In the present study, the toxicity of garlic EO against T. hirsuta and L. sulphureus was evaluated, with an $\mathrm{IC}_{50}$ value of 137.3 and $44.6 \mu \mathrm{g} / \mathrm{mL}$, respectively. These results agree with those of Xie et al. [2] who evaluated the antifungal activity of O. vulgare EO against $T$. hirsuta $\left(\mathrm{IC}_{50}=79.1 \mu \mathrm{g} / \mathrm{mL}\right)$ and L. sulphureus $\left(\mathrm{IC}_{50}=36.9 \mu \mathrm{g} / \mathrm{mL}\right)$. Similarly, Xie et al. [1] reported the inhibitory effect of $S$. aromaticum $\mathrm{EO}$ on T. hirsuta with an $\mathrm{IC}_{50}$ value of $124.9 \mu \mathrm{g} / \mathrm{mL}$. Earlier, Cinnamomum osmophloeum EO also showed a significant antifungal activity against L. sulphureus at $200 \mu \mathrm{g} / \mathrm{mL}[54,55]$. In addition, our results showed that diallyl disulfide and diallyl trisulfide demonstrated antifungal activity on wood decay fungi, T. hirsuta and L. sulphureus. Cheng et al. [56] showed that $\alpha$-cadinol had bioactivity against $L$. sulphureus with $\mathrm{IC}_{50}$ values of $9.9 \mu \mathrm{g} / \mathrm{mL}$. Cheng et al. [57] demonstrated that cinnamaldehyde $\left(\mathrm{IC}_{50}=35.3 \mu \mathrm{g} / \mathrm{mL}\right)$ and eugenol $\left(\mathrm{IC}_{50}=62.9 \mu \mathrm{g} / \mathrm{mL}\right)$ had bioactivity against L. sulphureus. Xie et al. [1] also demonstrated that the $\mathrm{IC}_{50}$ value of eugenol against T. hirsuta was $83.6 \mu \mathrm{g} / \mathrm{mL}$. In another investigation, Xie et al. [2] reported that carvacrol had bioactivity against $T$. hirsuta $\left(\mathrm{IC}_{50}=33.6 \mu \mathrm{g} / \mathrm{mL}\right)$ and L. sulphureus $\left(\mathrm{IC}_{50}=17.2 \mu \mathrm{g} / \mathrm{mL}\right)$. Geranial showed the antifungal activity against $T$. hirsuta $\left(\mathrm{IC}_{50}=56.6 \mu \mathrm{g} / \mathrm{mL}\right)$ and L. sulphureus $\left(\mathrm{IC}_{50}=33.3 \mu \mathrm{g} / \mathrm{mL}\right)$ [58]. Results from this study suggested that the garlic EO has an excellent antifungal activity.

Our results showed that diallyl trisulfide has stronger antifungal activity in T. hirsuta $\left(\mathrm{IC}_{50}=56.1 \mu \mathrm{g} / \mathrm{mL}\right)$ and L. sulphureus $\left(\mathrm{IC}_{50}=31.6 \mu \mathrm{g} / \mathrm{mL}\right)$, than diallyl disulfide in T. hirsuta $\left(\mathrm{IC}_{50}=116.2 \mu \mathrm{g} / \mathrm{mL}\right)$ and L. sulphureus $\left(\mathrm{IC}_{50}=73.2 \mu \mathrm{g} / \mathrm{mL}\right)$, whereas garlic EO had $\mathrm{IC}_{50}$ values of 137.3 and $44.6 \mu \mathrm{g} / \mathrm{mL}$ for T. hirsuta and L. sulphureus, respectively. Huang et al. [59] and Zhao et al. [41] also proved that the strongest fumigant component in the garlic EO is diallyl trisulfide. These results indicated that the fumigant toxicity of garlic EO may be ascribed to diallyl trisulfide. Earlier, Gándara-Ledezma et al. [49] showed that diallyl trisulfide had stronger inhibitory activity than diallyl disulfide against $B$. cinerea . Additionally, diallyl trisulfide has been reported to provide strong contact/fumigant toxicity against $S$. oryzae $\left(\mathrm{LD}_{50}=6.2 \mu \mathrm{g} / \mathrm{mg} ; \mathrm{LC}_{50}=8.4 \mathrm{mg} / \mathrm{L}\right)$, S. zeamais $\left(\mathrm{LD}_{50}=5.54 \mu \mathrm{g} / \mathrm{mg}\right.$; $\left.\mathrm{LC}_{50}=6.32 \mathrm{mg} / \mathrm{L}\right)$, and T. castaneum $\left(\mathrm{LD}_{50}=1.02 \mu \mathrm{g} / \mathrm{mg} ; \mathrm{LC}_{50}=0.83 \mathrm{mg} / \mathrm{L}\right)[59,60]$. Similarly, diallyl trisulfide (100\% mortality at $0.125 \mu \mathrm{L} / \mathrm{L}$ exposure for $48 \mathrm{~h}$ ) has also been shown to exhibit stronger toxicity than diallyl disulfide $(33 \%$ mortality at $0.125 \mu \mathrm{L} / \mathrm{L}$ exposure $48 \mathrm{~h}$ ) against $R$. speratus [34]. Diallyl trisulfide possessed stronger contact toxicity $\left(\mathrm{LC}_{50}\right.$ of $\left.2.79 \mu \mathrm{L} / \mathrm{L}\right)$ than diallyl disulfide $\left(\mathrm{LC}_{50}\right.$ of $37.06 \mu \mathrm{L} / \mathrm{L}$ ) against Bursaphelenchus xylophilus [61]. According to the literatures reported, diallyl trisulfide was more effective on $C$. chinensis than diallyl disulfide, and the $\mathrm{LD}_{50}$ values of diallyl trisulfide and diallyl disulfide are 0.64 and $11.04 \mu \mathrm{g} /$ adult, respectively [41]. The above conclusions indicate that the main components of garlic EO, in particular diallyl trisulfide, are promising in pest management.

EO is generally regarded as a green, safe, and degradable substance, thus it is very popular in antibacterial and insecticidal applications [1-3]. However, due to the low water solubility of EOs, their use is often limited [42,62]. The easiest method to solve this problem is to encapsulate the EO in an emulsion or nanoemulsion [63]. Prior to this, emulsion delivery systems were employed to encapsulate various EOs, including antimicrobial [62,64-66] and insecticidal $[42,63,67]$. Simultaneously, nanoformulations can improve the bioavailability and stability of pesticides without using organic toxic solvents [42]. Our results showed that DAT nanoemulsions demonstrated enhanced antifungal activity on wood decay fungi, 
T. hirsuta and L. sulphureus. This is consistent with the previously reported studies using sunflower microemulsion [68]. Earlier, Katata-Seru et al. [66] demonstrated that garlic EO nanoemulsions had better inhibition levels against Escherichia coli than garlic EO. Similarly, the toxicity of nanoemulsions and the normal emission of garlic had $\mathrm{LC}_{50}$ values of 298.2 and $584.9 \mu \mathrm{g} / \mathrm{mL}$ against Aceria oleae and 309.6 and $677.8 \mu \mathrm{g} / \mathrm{mL}$ against Tegolophus hassani, respectively [42].

In the present study, the amount of surfactant has a significant effect on the droplet size produced, and higher concentrations of surfactant led to the formation of smaller droplets. These results agree with those of Chang et al. [62] and Anton and Vandamme [69] who also reported that higher concentrations of surfactant led to the formation of smaller droplets. This may be due to a higher concentration of surfactant molecules that diffuse from the organic phase into the water phase during contact, which promotes the formation of finer oil droplets at the oil-water boundary [70].

Additionally, the antifungal activity of the nanoemulsions increases with the increase of the DAT concentration in the organic phase, whereby, if the nanoemulsions contain a higher level of DAT in their lipid phase, a smaller amount of DAT is required to completely inhibit the growth of wood decay. This corresponds to the previously reported study on the effect of the concentration of active ingredients in the lipid phase of nanoemulsions on the antibacterial efficacy $[44,65]$.

In addition, it is known in the literature that most of the EOs and their major components can destroy the permeability of fungal cell membranes, cause the outflow of intracellular components, and inhibit spore germination and hyphae growth [71-73]. Martins et al. [23] reviewed the antibacterial mechanism of allicin, interaction with thiolcontaining enzymes, inhibition of acetyl-CoA synthetases, and inhibition of spore germination and hyphae growth of multiple mechanisms. Therefore, the exact mode of action and target of garlic EO and its main constitutes in inhibiting the tested wood-rotting fungi in this study need to be revealed and confirmed by further experiments.

As far as we know, there was no report on the antifungal efficacy of garlic EO and its major constituents against $T$. hirsuta and L. sulphureus. This study showed the potential of garlic EO and its major components to control wood decay fungi, especially for diallyl trisulfide. In addition, in this study, the size of the oil droplets produced in the DAT nanoemulsions decreased with the increase of the surfactant concentration, and as the amount of DAT in the lipid phase increases, the antifungal activity of the nanoemulsions increases. These findings show that the nanoemulsions of the major component of garlic EO, diallyl trisulfide, has the potential to develop as a natural wood preservation and warrants further exploration.

\section{Materials and Methods}

\subsection{Fungi}

White-rot fungus, Trametes hirsuta (CFCC 84683) and brown-rot fungus, Laetiporus sulphureus (CFCC 86368), purchased from the China Forestry Culture Collection Center (CFCC), were used for this test.

\subsection{Essential Oil and Chemicals}

Garlic oil, purchased from Guangzhou Daily Chemical Co., Ltd. (Guangzhou, China); diallyl sulfide (DAS), procured from Alfa Aesar (China) Chemical Co., Ltd. (Shanghai, China); diallyl disulfide (DAD), purchased from Tokyo (Shanghai) Chemical Industry Co., Ltd. (Shanghai, China); diallyl trisulfide (DAT), purchased from Toronto Research Chemicals (TRC); Tween-20, purchased from Shenggong Bioengineering (Shanghai) Co., Ltd. (Shanghai, China).

\subsection{GC-MS}

An Agilent 6890A GC combined with an Agilent 5975C MS were used to analyze the components of the samples. Chromatographic conditions: The initial setting of the column 
temperature was set from 50 to $250{ }^{\circ} \mathrm{C}$, at a rate of $10^{\circ} \mathrm{C} / \mathrm{min}$ and held at $250{ }^{\circ} \mathrm{C}$ for $10 \mathrm{~min}$. Helium was the carrier gas and the flow rate was $1 \mathrm{~mL} / \mathrm{min}$. The identification of the chemical composition of EOs was based on the retention index related to n-alkanes, matching with computer mass spectrometry databases, and in comparison with standard samples.

\subsection{Nanoemulsion Preparation}

The nanoemulsion spontaneous emulsification procedure was followed by the method of Chang et al. [62] with slight modifications. In short, a spontaneous emulsification was added to the oil phase (containing different contents of DAT and Tween-20) into the aqueous phase at room temperature $\left(\sim 26^{\circ} \mathrm{C}\right)$ and stirred with a magnetometer $(500 \mathrm{rpm})$. The specific operation was as follows: First, $10 \mathrm{~g}$ of oil (DAT) and $10 \mathrm{~g}$ of Tween-20 were mixed, and then the mixture was slowly titrated into $80 \mathrm{~g}$ of water phase at a rate of $1 \mathrm{~mL} / \mathrm{min}$.

\subsection{Particle Size Measurements}

A dynamic light scattering instrument (NKT-N9H, Nikete Analytical Instrument, Jinan, Shangdong, China) was used to measure the particle size and average particle size (Z-averages) of the nanoemulsions. Before the measurement, the sample was diluted 100 times with distilled water. The particle size of the sample was obtained by measuring the fluctuation of the scattered light intensity of the sample. The measurement was repeated 10 times for each sample.

\subsection{Antifungal Assay}

Using the method of Xie et al. [2], the two wood-rotting fungi were tested against garlic EO and its major components. The concentration gradient of each agent was 400, 200, 100, 50, $25 \mu \mathrm{g} / \mathrm{mL}$, and the blank Potato Dextrose Agar medium (PDA) petri dish was used as a control and placed at a $26 \pm 1{ }^{\circ} \mathrm{C}$ incubator for 5-7 days. Each treatment was set for three repetitions. When the control mycelium was overgrown in the petri dish, we observed and measured the circle diameter.

$$
\text { Inhibition }(\%)=(1-\mathrm{Da} / \mathrm{Db}) \times 100 \%
$$

where $\mathrm{Da}$ is the growth diameter of hyphae in the treated plate $(\mathrm{mm})$, and $\mathrm{Db}$ is the growth diameter of hyphae in the control plate $(\mathrm{mm})$.

\subsection{Statistical Analyses}

All of the data in this experiment were used by SPSS19.0 for ANOVA and evaluated the difference according to the pairwise comparison test of Scheffe's method. When $p<0.05$, the data difference is considered significant. Each treatment was repeated three times. The $\mathrm{IC}_{50}$ value is obtained by the regression analysis, which is performed by SPSS.

Author Contributions: Conceptualization, X.G., X.S. and H.L.; methodology, X.G., X.S. and H.L.; software, X.G.; validation, X.G., X.S. and H.L.; formal analysis, X.G.; investigation, X.G.; resources, X.G.; data curation, X.G.; writing-original draft preparation, X.G. and H.L.; writing-review and editing, X.G. and H.L.; visualization, X.G.; supervision, X.S. and H.L.; project administration, H.L. All authors have read and agreed to the published version of the manuscript.

Funding: This research received no external funding.

Institutional Review Board Statement: Not applicable.

Informed Consent Statement: Not applicable.

Data Availability Statement: Not applicable.

Conflicts of Interest: The authors declare no conflict of interest.

Sample Availability: Not available. 


\section{References}

1. Xie, Y.; Yang, Z.; Cao, D.; Rao, F.; Ding, H.; Zhang, D. Antitermitic and antifungal activities of eugenol and its congeners from the flower buds of Syzgium aromaticum (clove). Ind. Crop. Prod. 2015, 77, 780-786. [CrossRef]

2. Xie, Y.; Wang, Z.; Huang, Q.; Zhang, D. Antifungal activity of several essential oils and major components against wood-rot fungi. Ind. Crop. Prod. 2017, 108, 278-285. [CrossRef]

3. Yang, X.; Han, H.; Li, B.; Zhang, D.; Zhang, Z.; Xie, Y. Fumigant toxicity and physiological effects of spearmint (Mentha spicata, Lamiaceae) essential oil and its major constituents against Reticulitermes dabieshanensis. Ind. Crop. Prod. 2021, 171, 113894. [CrossRef]

4. Wu, C.L.; Chien, S.C.; Wang, S.Y.; Ku, Y.H.; Chang, S.T. Structure-activity relationships of cadinane-type sesquiterpene derivatives against wood-decay fungi. Holzforschung 2005, 59, 620-627. [CrossRef]

5. Chen, P.S.; Chen, Y.H.; Yeh, T.F.; Chang, S.T. Mechanism of decay resistance of heartwood extracts from Acacia confusa against the brown-rot fungus Laetiporus sulphureus. Wood Sci. Technol. 2014, 48, 451-465. [CrossRef]

6. Wang, L.; Chen, S.S.; Tsang, D.C.W.; Poon, C.S.; Shih, K. Recycling contaminated wood into eco-friendly particleboard using green cement and carbon dioxide curing. J. Clean. Prod. 2016, 137, 861-870. [CrossRef]

7. Brocco, V.F.; Paes, J.B.; Costa, L.G.; Brazolin, S.; Arantes, M.D.C. Potential of teak heartwood extracts as a natural wood preservative. J. Clean. Prod. 2017, 142, 2093-2099. [CrossRef]

8. Mohammed, S.A.; Madhan, B.; Demissie, B.A.; Velappan, B.; Selvi, A.T. Rumex abyssinicus (mekmeko) Ethiopian plant material for preservation of goat skins: Approach for cleaner leather manufacture. J. Clean. Prod. 2016, 133, 1043-1052. [CrossRef]

9. Tchinda, J.B.S.; Ndikontar, M.K.; Belinga, A.D.F.; Mounguengui, S.; Njankouo, J.M.; Durmaçay, S.; Gerardin, P. Inhibition of fungi with wood extractives and natural durability of five Cameroonian wood species. Ind. Crops Prod. 2018, 123, 183-191. [CrossRef]

10. Salem, M.Z.M.; Zidan, Y.E.; Mansour, M.M.A.; El-Hadidi, N.M.N.; Abo-Elgat, W.A.A. Antifungal activities of two essential oils used in the treatment of three commercial woods deteriorated by five common mold fungi. Int. Biodeter. Biodeg. 2016, 106, 88-96. [CrossRef]

11. Barbero-López, A. Antifungal activity of several vegetable origin household waste extracts against wood-decaying fungi in vitro. Waste Biomass Valori. 2021, 12, 1237-1241. [CrossRef]

12. Bi, Z.; Zhao, Y.; Morrell, J.J.; Lei, Y.; Yan, L. The antifungal mechanism of konjac flying powder extract and its active compounds against wood decay fungi. Ind. Crop. Prod. 2021, 164, 113406. [CrossRef]

13. Gupta, H.; Sharma, K.R.; Sharma, J.N. Economically Feasible Wood Biopreservation Platform in Lannea coromandelica (Houtt.) Merr. Against Wood Rotting Fungus Through Bio-Prospecting Weed Extracts. Front. Plant Sci. 2021, 12, 696747. [CrossRef] [PubMed]

14. Kimbaris, A.C.; Siatis, N.G.; Daferera, D.J.; Tarantilis, P.A.; Pappas, C.S.; Polissiou, M.G. Comparison of distillation and ultrasoundassisted extraction methods for the isolation of sensitive aroma compounds from garlic (Allium sativum). Ultrason Sonochem. 2006, 13, 54-60. [CrossRef]

15. Kimbaris, A.C.; Kioulos, E.; Koliopoulos, G.; Polissiou, M.G.; Michaelakis, A. Coactivity of sulfide ingredients: A new perspective of the larvicidal activity of garlic essential oil against mosquitoes. Pest. Manag. Sci. 2009, 65, 249-254. [CrossRef] [PubMed]

16. Batiha, G.E.; Beshbishy, A.M.; Wasef, L.G.; Elewa, Y.H.A.; Al-Sagan, A.A.; El-Hack, M.E.A.; Taha, A.E.; Abd-Elhakim, Y.M.; Devkota, H.P. Chemical Constituents and Pharmacological Activities of Garlic (Allium sativum L.): A Review. Nutrients 2020, 12, 872. [CrossRef]

17. Chen, Y.; Sun, J.; Dou, C.; Li, N.; Kang, F.; Wang, Y.; Cao, Z.; Yang, X.; Dong, S. Alliin attenuated RANKL-induced osteoclastogenesis by scavenging reactive oxygen species through inhibiting Nox1. Int. J. Mol. Sci. 2016, 17, 1516. [CrossRef]

18. Zhang, X.; Zhu, Y.; Duan, W.; Feng, C.; He, X. Allicin induces apoptosis of the MGC-803 human gastric carcinoma cell line through the p38 mitogen-activated protein kinase/caspase-3 signaling pathway. Mol. Med. Rep. 2015, 11, 2755-2760. [CrossRef] [PubMed]

19. Kuda, T.; Iwai, A.; Yano, T. Effect of red pepper Capsicum annuum var. conoides and garlic Allium sativum on plasma lipid levels and cecal microflora in mice fed beef tallow. Food Chem. Toxicol. 2004, 42, 1695-1700. [CrossRef]

20. Zhai, B.; Zhang, C.; Sheng, Y.; Zhao, C.; He, X.; Xu, W.; Huang, K.; Luo, Y. Hypoglycemic and hypolipidemic effect of S-allylcysteine sulfoxide (alliin) in DIO mice. Sci. Rep. 2018, 8, 3527. [CrossRef]

21. Abdel-Hafeez, E.H.; Ahmad, A.K.; Kamal, A.M.; Abdellatif, M.Z.; Abdelgelil, N.H. In vivo antiprotozoan effects of garlic (Allium sativum) and ginger (Zingiber cinale) extracts on experimentally infected mice with Blastocystis spp. Parasitol. Res. 2015, 114, 3439-3444. [CrossRef]

22. Alorainy, M.S. Evaluation of antimicrobial activity of garlic (Allium sativum) against E. coli O157:H7. J. Agric. Veterina Sci. 2011, 4, 149-157.

23. Martins, N.; Petropoulos, S.; Ferreira, I.C.F.R. Chemical composition and bioactive compounds of garlic (Allium sativum L.) as affected by pre- and post-harvest conditions: A review. Food Chem. 2016, 211, 41-50. [CrossRef]

24. Drobiova, H.; Thomson, M.; Al-Qattan, K.; Peltonen-Shalaby, R.; Al-Amin, Z.; Ali, M. Garlic increases antioxidant levels in diabetic and hypertensive rats determined by a modified peroxidase method. Evid.-Based Complement. Altern. Med. 2011, 2011, 703049. [CrossRef] [PubMed]

25. Liu, S.G.; Ren, P.Y.; Wang, G.Y.; Yao, S.X.; He, X.J. Allicin protects spinal cord neurons from Glutamate-induced oxidative stress through regulating the heat shock protein 70/inducible nitric oxide synthase pathway. Food Funct. 2015, 6, 321-330. [CrossRef] 
26. Bayan, L.; Koulivand, P.H.; Gorji, A. Garlic: A review of potential therapeutic effects. Avicenna J. Phytomed. 2014, 4, 1-14. [PubMed]

27. Jarial, M.S. Toxic effect of garlic extracts on the eggs of Aedes aegypti (Diptera: Culicidae): A scanning electron microscopic study. J. Med. Entomol. 2001, 38, 446-450. [CrossRef]

28. Campbell, C.; Gries, R.; Khaskin, G.; Gries, G. Organosulphur constituents in garlic oil elicit antennal and behavioural responses from the yellow fever mosquito. J. Appl. Entomol. 2011, 135, 374-381. [CrossRef]

29. Muturi, E.J.; Ramirez, J.L.; Zilkowski, B.; Flor-Weiler, L.B.; Rooney, A.P. Ovicidal and Larvicidal Effects of Garlic and Asafoetida Essential Oils Against West Nile Virus Vectors. J. Insect Sci. 2018, 18, 1-6. [CrossRef] [PubMed]

30. Martinez-Velazquez, M.; Rosario-Cruz, R.; Castillo-Herrera, G.; Flores-Fernandez, J.M.; Alvarez, A.H.; Lugo-Cervantes, E. Acaricidal effect of essential oils from Lippia graveolens (Lamiales: Verbenaceae), Rosmarinus officinalis (Lamiales: Lamiaceae), and Allium sativum (Liliales: Liliaceae) against Rhipicephalus (Boophilus) microplus (Acari: Ixodidae). J. Med. Entomol. 2011, 48, 822-827. [CrossRef]

31. Ho, S.H.; Koh, L.; Ma, Y.; Huang, Y.; Sim, K.Y. The oil of garlic, Allium sativum L. (Amaryllidaceae), as a potential grain protectant against Tribolium castaneum (Herbst) and Sitophilus zeamais Motsch. Postharvest Biol. Technol. 1996, 9, 41-48. [CrossRef]

32. Chiam, W.Y.; Huang, Y.; Chen, S.X.; Ho, S.H. Toxic and antifeedant effects of allyl disulfide on Tribolium castaneum (Coleoptera: Tenebrionidae) and Sitophilus zeamais (Coleoptera: Curculionidae). J. Econ. Entomol. 1999, 92, 239-245. [CrossRef]

33. Yang, F.L.; Zhu, F.; Lei, C.L. Garlic essential oil and its major component as fumigants for controlling Tribolium castaneum (Herbst) in chambers filled with stored grain. J. Pest. Sci. 2010, 83, 311-317. [CrossRef]

34. Park, I.K.; Shin, S.C. Fumigant activity of plant essential oils and components from garlic (Allium sativum) and clove bud (Eugenia caryophyllata) oils against the Japanese termite (Reticulitermes speratus Kolbe). J. Agric. Food Chem. 2005, 53, 4388-4392. [CrossRef]

35. Mikhaiel, A.A. Potential of some volatile oils in protecting packages of irradiated wheat flour against Ephestia kuehniella and Tribolium castaneum. J. Stored Prod. Res. 2011, 47, 357-364. [CrossRef]

36. Ileke, K.D.; Olotuah, O.F. Bioactivity of Anacardium occidentale (L.) and Allium sativum (L.) powders and oils extracts against cowpea bruchid, Callosobruchus maculatus (Fab.) [Coleoptera: Chrysomelidae]. Int. J. Biol. 2012, 4, 96-103. [CrossRef]

37. Yang, F.L.; Zhu, F.; Lei, C.L. Insecticidal activities of garlic substances against adults of grain moth, Sitotroga cerealella (Lepidoptera: Gelechiidae). Insect Sci. 2012, 19, 205-212. [CrossRef]

38. Plata-Rueda, A.; Martínez, L.C.; Santos, M.H.D.; Fernandes, F.L.; Wilcken, C.F.; Soares, M.A.; Serrão, J.E.; Zanuncio, J.C. Insecticidal activity of garlic essential oil and their constituents against the mealworm beetle, Tenebrio molitor Linnaeus (Coleoptera: Tenebrionidae). Sci. Rep. 2017, 7, 46406. [CrossRef] [PubMed]

39. Landolt, P.J.; Hofstetter, R.W.; Biddick, L.L. Plant essential oils as arrestants and repellents for neonate larvae of the codling moth (Lepidoptera: Tortricidae). Environ. Entomol. 1999, 28, 954-960. [CrossRef]

40. Attia, S.; Grissa, K.L.; Mailleux, A.C.; Lognay, G.; Heuskin, S.; Mayoufi, S.; Hance, T. Effective concentrations of garlic distillate (Allium sativum) for the control of Tetranychus urticae (Tetranychidae). J. Appl. Entomol. 2012, 136, 302-312. [CrossRef]

41. Zhao, N.N.; Zhang, H.; Zhang, X.C.; Luan, X.B.; Zhou, C.; Liu, Q.Z.; Shi, W.P.; Liu, Z.L. Evaluation of Acute Toxicity of Essential Oil Of Garlic (Allium sativum) and Its Selected Major Constituent Compounds Against Overwintering Cacopsylla chinensis (Hemiptera: Psyllidae). J. Econ. Entomol. 2013, 106, 1349-1354. [CrossRef] [PubMed]

42. Mossa, A.T.H.; Afia, S.I.; Mohafrash, S.M.M.; Abou-Awad, B.A. Formulation and characterization of garlic (Allium sativum L.) essential oil nanoemulsion and its acaricidal activity on eriophyid olive mites (Acari: Eriophyidae). Environ. Sci. Pollut. Res. 2018, 25, 10526-10537. [CrossRef]

43. Preisser, R.H.; Anderson, T.D.; Demares, F.; Bloomquist, J.R.; Gerrard, D.E. Acaricidal effects of fresh garlic juice on adult ham mite, Tyrophagus putrescentiae (Schrank). J. Stored Prod. Res. 2018, 79, 73-78. [CrossRef]

44. Chege, E.W.; Kimaru, S.K. Effects of Tithonia diversifolia and Allium sativum extracts on Colletotrichum gloeosporioides, the causal agent of anthracnose in avocado. All Life 2021, 14, 209-214. [CrossRef]

45. Senouci, H.; Benyelles, N.G.; Dib, M.E.A.; Costa, J.; Muselli, A. Chemical Composition and Combinatory Antifungal Activities of Ammoides verticillata, Allium sativum and Curcuma longa Essential Oils Against Four Fungi Responsible for Tomato Diseases. Comb. Chem. High Throughput Screen. 2020, 23, 196-204. [CrossRef]

46. Juárez-Segovia, K.G.; Díaz-Darcía, E.J.; Méndez-López, M.D.; Pina-Canseco, M.S.; Pérez-Santiago, A.D.; Sánchez-Medina, M.A. Effect of garlic extracts (Allium sativum) on the development in vitro of Aspergillus parasiticus and Aspergillus niger. Polibotánica 2019, 47, 99-111. [CrossRef]

47. Yassin, M.A.; Moslem, M.A.; El-Samawaty, A.E.R.M.A.; El-Shikh, M.S. Effectiveness of Allium sativum in Controlling Sorghum Grain Molding Fungi. J. Pure Appl. Microbio. 2013, 7, 101-107.

48. Üstüner, T.; Kordali, S.; Bozhüyük, A.U. Herbicidal and Fungicidal Effects of Cuminum cyminum, Mentha longifolia and Allium sativum Essential Oils on Some Weeds and Fungi. Rec. Nat. Prod. 2018, 12, 619-629. [CrossRef]

49. Gándara-Ledezma, A.; Corrales-Maldonado, C.; Rivera-Domínguez, M.; Martínez-Téllez, M.A.; Vargas-Arispuro, I. Post-harvest control of gray mold in table grapes using volatile sulfur compounds from Allium sativum. J. Sci. Food Agric. 2015, 95, 497-503. [CrossRef]

50. El-Samawaty, A.M.A.; Moslem, M.A.; Yassin, M.A.; Sayed, S.R.M.; El-Shikh, M.S. Control of Grape Blue Molding Penicillia by Allium sativum. J. Pure Appl. Microbio. 2013, 7, 1047-1053. 
51. Kocic-Tanackov, S.; Dimic, G.; Levic, J.; Tanackov, I.; Tepic, A.; Vujicic, B.; Gvozdanovic-Varga, J. Effects of onion (Allium cepa L.) and garlic (Allium sativum L.) essential oils on the Aspergillus versicolor growth and sterigmatocystin production. J. Food Sci. 2012, 77, M278-M284. [CrossRef] [PubMed]

52. Li, R.; Chen, W.C.; Wang, W.P.; Tian, W.Y.; Zhang, X.G. Extraction of essential oils from garlic (Allium sativum) using ligarine as solvent and its immunity activity in gastric cancer rat. Med. Chem. Res. 2010, 19, 1092-1105. [CrossRef]

53. Casella, S.; Leonardi, M.; Melai, B.; Fratini, F.; Pistelli, L. The role of diallyl sulfides and dipropyl sulfides in the in vitro antimicrobial activity of the essential oil of garlic, Allium sativum L., and leek, Allium porrum L. Phytother. Res. 2013, 27, 380-383. [CrossRef]

54. Wang, S.Y.; Chen, P.F.; Chang, S.T. Antifungal activities of essential oils and their constituents from indigenous cinnamon (Cinnamomum osmophloeum) leaves against wood decay fungi. Bioresour. Technol. 2005, 96, 813-818. [CrossRef]

55. Cheng, S.S.; Liu, J.Y.; Hsui, Y.R.; Chang, S.T. Chemical polymorphism and antifungal activity of essential oils from leaves of different provenances of indigenous cinnamon (Cinnamomum osmophloeum). Bioresour. Technol. 2006, 97, 306-312. [CrossRef]

56. Cheng, S.S.; Wu, C.L.; Chang, H.T.; Kao, Y.T.; Chang, S.T. Antitermitic and antifungal activities of essential oil of Calocedrus fromosana leaf and its compounds. J. Chem. Ecol. 2004, 30, 1957-1967. [CrossRef]

57. Cheng, S.S.; Liu, J.Y.; Chang, E.H.; Chang, S.T. Antifungal activity of cinnamaldehyde and eugenol congeners against wood-rot fungi. Bioresour. Technol. 2008, 99, 5145-5149. [CrossRef]

58. Xie, Y.; Yang, X.; Han, H.; Zhang, Z.; Zhang, D. Antifungal activity and mechanism of the essential oils from Litsea (Litsea cubeba), Melissa (Melissa officinalis), Palmarosa (Cymbopogon martini) and Verbena (Verbena officinalis) and their major active constituents against Trametes hirsuta and Laetiporus sulphureus. Res. Squ. Preprint. 2021. [CrossRef]

59. Huang, Y.; Chen, S.X.; Ho, S.H. Bioactivities of methyl allyl disulfide and diallyl trisulfide from essential oil of garlic to two species of stored-product pests, Sitophilus zeamais (Coleoptera: Curculionidae) and Tribolium castaneum (Coleoptera: Tenebrionidae). J. Econ. Entomol. 2000, 93, 537-543. [CrossRef]

60. Koul, O. Biological activity of volatile di-n-propyl disulfide from seeds of neem, Azadirachta indica (Meliaceae), to two species of stored grain pests, Sitophilus oryzae (L.) and Tribolium castaneum (Herbst). J. Econ. Entomol. 2004, 97, 1142-1147. [CrossRef]

61. Park, I.K.; Park, J.Y.; Kim, K.H.; Choi, K.S.; Choi, I.H.; Kim, C.S.; Shin, S.C. Nematicidal activity of plant essential oils and components from garlic (Allium sativum) and cinnamon (Cinnamomum verum) oils against the pine wood nematode (Bursaphelenchus xylophilus). Nematology 2005, 7, 767-774. [CrossRef]

62. Chang, Y.; McLandsborough, L.; McClements, D.J. Physicochemical Properties and Antimicrobial Efficacy of Carvacrol Nanoemulsions Formed by Spontaneous Emulsification. J. Agric. Food Chem. 2013, 61, 8906-8913. [CrossRef] [PubMed]

63. Fernandes, C.P.; Almeida, F.B.; Silveira, A.N.; Gonzalez, M.S.; Mello, C.B.; Feder, D.; Apolinário, R.; Santos, M.G.; Carvalho, J.C.T.; Tietboh, L.A.C.; et al. Development of an insecticidal nanoemulsion with Manilkara subsericea (Sapotaceae) extract. J. Nanobiotechnol. 2014, 12, 22. [CrossRef] [PubMed]

64. Ziani, K.; Chang, Y.; McLandsborough, L.; McClements, D.J. Influence of surfactant charge on antimicrobial efficacy of surfactantstabilized thyme oil nanoemulsions. J. Agric. Food Chem. 2011, 59, 6247-6255. [CrossRef]

65. Chang, Y.; McLandsborough, L.; McClements, D.J. Physical properties and antimicrobial efficacy of thyme oil nanoemulsions: Influence of ripening inhibitors. J. Agric. Food Chem. 2012, 60, 12056-12063. [CrossRef] [PubMed]

66. Katata-Seru, L.; Lebepe, T.C.; Aremu, O.S.; Bahadur, I. Application of Taguchi method to optimize garlic essential oil nanoemulsions. J. Mol. Liq. 2017, 244, 279-284. [CrossRef]

67. Anjali, C.; Sharma, Y.; Mukherjee, A.; Chandrasekaran, N. Neem oil (Azadirachta indica) nanoemulsion-a potent larvicidal agent against Culex quinquefasciatus. Pest. Manag. Sci. 2012, 68, 158-163. [CrossRef]

68. Anjali, C.H.; Dash, M.; Chandrasekaran, N.; Mukherjee, A. Antibacterial activity of sunflower oil microemulsion. Int. J. Pharm. Pharm. Sci. 2010, 2, 123-128.

69. Anton, N.; Vandamme, T.F. The universality of low-energy nano-emulsification. Int. J. Pharm. 2009, 377, 142-147. [CrossRef]

70. Lamaallam, S.; Bataller, H.; Dicharry, C.; Lachaise, J. Formation and stability of miniemulsions produced by dispersion of water/oil/surfactants concentrates in a large amount of water. Colloids Surf. A 2005, 270, 44-51. [CrossRef]

71. Zhou, D.; Wang, Z.; Li, M.; Xing, M.; Xian, T.; Tu, K. Carvacrol and eugenol effectively inhibit Rhizopus stolonifer and control postharvest soft rot decay in peaches. J. Appl. Microbiol. 2017, 124, 166-178. [CrossRef] [PubMed]

72. Yan, J.; Wu, H.; Shi, F.; Wang, H.; Chen, K.; Feng, J.; Jia, W. Antifungal activity screening for mint and thyme essential oils against Rhizopus stolonifer and their application in postharvest preservation of strawberry and peach fruits. J. Appl. Microbiol. 2020, 130, 1993-2007. [CrossRef]

73. Souza, D.P.; Pimentel, R.B.Q.; Santos, A.S.; Albuquerque, P.M.; Fernandes, A.V.; Junior, S.D.; Oliveira, J.T.A.; Ramos, M.V.; Rathinasabapathi, B.; Goncalves, J.F.C. Fungicidal properties and insights on the mechanisms of the action of volatile oils from Amazonian Aniba trees. Ind. Crops Prod. 2020, 143, 111914. [CrossRef] 